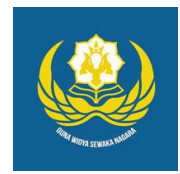

Jurnal Analogi Hukum

Journal Homepage: https://ejournal.warmadewa.ac.id/index.php/analogihukum

\title{
Pembuktian dan Penjatuhan Putusan Pidana Terhadap Terdakwa Tindak Pidana Penganiayaan (Studi Kasus Putusan Nomor 26/Pid.B/2016/Pn.Tab.)
}

\author{
I Putu Hendra Setyawan*, I Made Arjaya dan Diah Gayatri Sudibya \\ Universitas Warmadewa, Denpasar-Bali, Indonesia \\ *hendrasetyawan@gmail.com
}

\begin{abstract}
How To Cite:
Pramana, I, P, B., Arjaya, I, M., Arini, D, G, D. (2020). Pembuktian dan Penjatuhan Putusan Pidana Terhadap Terdakwa Tindak Pidana Penganiayaan (Studi Kasus Putusan Nomor 26/Pid.B/2016/Pn.Tab.). Jurnal Analogi Hukum. 2 (3). 310-314. https://doi.org/10.22225/ ah.2.3.2504.310-314

Abstract - Crime is an act or series of acts that can be subject to criminal law. One form of crime is persecution. Persecution is a form of harming or torturing people or intentionally reducing and damaging the health of others. The main problem is how the application of sanctions for criminal acts of abuse by public prosecutors and how the judges consider in the case of criminal acts of abuse. The research method used in writing this thesis is a type of normative legal research. Whereas the approach uses the conceptual approach, the legal approach and the case approach. The application of criminal sanctions for maltreatment by public prosecutors refers to article 351 paragraphs (1) of the Criminal Code which has been adjusted to article 3 of the Supreme Court Regulation of the Republic of Indonesia No.2 of 2012 concerning adjustments to the limits of minor criminal offenses and the amount of fines in KHUP. Whereas the judge considers each indictment from the public prosecutor, the defendant has fulfilled a single indictment and is based on the process of examining evidence, namely testimony of witnesses, letters, statements of the defendant, instructions, and evidence. In the trial the facts that ordinary crimes had been committed were proven. Thus the Panel of Judges ruled with a sentence of 4 (four) months imprisonment.
\end{abstract}

Keywords: Proof; Criminal Verdict; Persecution

\begin{abstract}
Abstrak - Tindak pidana merupakan suatu perbuatan atau rangkaian perbuatan yang dapat dikenakan hukum pidana. Salah satu bentuk dari tindak pidana adalah penganiayaan. Yang diaksudkan dengan penganiayaan yaitu berbuat menyiksa, menyakiti dan sengaja merusak dan mengurangi kesehatan orang. Pokok permasalahannya adalah bagaimana penerapan sanksi tindak pidana penganiayaan oleh jaksa penuntut umum dan bagaimana pertimbangan hakim pada putusan perkara tindak pidana penganiayaan. Tipe hukum normatif yang saya gunakan di penulisan penelitian ini. Sedangkan pendekatan masalah menggunakan pendekatan konseptual, pendekatan perundang-undangan dan pendekatan kasus. Penerapan sanksi tindak pidana penganiayaan oleh jaksa penuntut umum mengacu pada pasal 351 ayat (1) KUHP yang pantas dengan pasal 3 Peraturan Mahkamah Agung Republik Indonesia No. 2 Tahun 2012 tentang penyesuaian batas tindak pidana ringan danjumlah denda dalam KHUP. Sedangkan hakim mempertimbangkan setiap dakwaan dari jaksa penuntut umum, maka terdakwa telah memenuhi dakwaan tunggal dan berdasarkan proses pemeriksaan alat bukti yakni keterangan saksi-saksi, surat, keterangan terdakwa, petunjuk, dan barang bukti. Dalam persidangan sudah dibuktikan bukti-bukti bahwa telah terjadi tindak pidana penganiayaan biasa. Dengan demikian Majelis Hakim menjatuhkan putusan dengan pidana kurangan penjara 4 (empat) bulan.
\end{abstract}

Kata Kunci: Pembuktian; Putusan Pidana; Penganiayaan.

\section{Pendahuluan}

Manusia membutuhkan orang lain dan lingkungan sosial mereka sebagai tempat untuk bersosialisasi karena manusia iyalah makhluk sosial. Bersoaialisasi dan berinteraksi itu hal yang di butuhkan oleh manusia oleh karena itu manusia mebutuhkan lingkungan sosial, Manusiapun berlakunya yang sebagai makhluk sosial saling keterlibatan dan ketergantungan 
dengan tempat yang ditinggalinya dan lingkungan skitar. Buat kesinambungan hidup sejenisnya individu bertindak sosial dengan cara mengeksploitasi alam dan lingkungannya tapi tetap menjaganya akan tetapi suatu potensi besar yang berada dalam diri manusia itu barangkali berkembang bila dia belajar dan tinggal ditengah manusia.

Dukungan dari individu lain diperlukan, agar manusia bisa melakukan kegiatankegiatannya untuk kehidupannya kelak dan untuk membangun potensi kemanusiannya agar terciptanya kehidupan yang selaras.

Terkadang didalam ikatan antara individu terdapat suatu perdebatan antara kebutuhan dan tujuanya. sehingga dapat melahirkan suatu perselisihan antara manusia yang satu, atas manusia lainnya. Hal-hal itulah yang dapat mengganggu keserasian dan keharmonisan dalam kehidupan masyarakat. Maka untuk itu diperlukan adanya ketentuan-ketentuan atau dalil-dalil yang nantinya akan bermanfaat untuk menjaga, mencipkatan hubungan bermasyarakat yang senantiasa selaras. Masalah kejahatan memang selalu menuntut perhatian yang serius dari waktu ke waktu. Kitab Undang-Undang Hukum Pidana dalam buku kedua sudah mengatur tentang kejahatan. Suatu perbuatan itu dikatakan kejahatan apabila melanggar ketentuan dalam buku kedua Kitab UndangUndang Hukum Pidana (Puspitasari \& Rofikah, 2019).

Setelan ketentuan-ketentuan, kode etik yang dimaksudkan tidak lain yakni hukum. Dibuatnya hukum untuk menata kehidupan bermayarakat guna menciptakan suatu keamanan. "a tool of social control" ialah salah satu cerminan dari fungsi hukum. Hukum sebagai sosial kontrol, sosial engineering dan soasial welfare Berperan aktif sebagai sesuatu yang dapat menetapkan tingkah laku manusia yang menyimpang terhadap aturan hukum. Sehingga hukum dapat memberikan sanksi atau tindakan terhadap si pelanggar (L.Diab, 2014). manfaat hukum selaku alat pengendali social yang di terangkan selaku manfaat hukum dalam penetapan perilaku yang dianggap sebagai perbuatan yang menyimpang akan aturan hukum serta sanksi, tindakan apa yang seharusnya dijatuhkankepada hukum apabila penyimpangan terjadi (Ali, 2002).

Hukum pidana adalah keseluruhan atas peraturan-peraturan yang menentukan perbuatan apa yang tidak boleh dilakukan sertatergolong kedalam suatu tindak pidana. Bersama hukuman apa yang akan ditentukan dan dijatuhkan kepada si pelaku.
Dilarang oleh aturan hukum, melawan hukum, pelakunya diancam dengan pidana,dan merugikan masyaakat ialah sifat-sifat itu boleh dikatakan sebagai suatu perbuatan tindak pidana. Melakukan suatu perbuatan yang dilarang oleh aturan hukum serta ancaman pidana (bersifat aktif) dan tidk melakukan yang sebenarnya diharuskan oleh hukum (bersifat pasif) yaitu merupakan pengertian dari tindak pidana. Macam-macam pidana penganiayaan yang terjadi dalam kehidupan bermasyrakat sehingga dapat menyebabkan hilangnya nyawa dari seseorang. Dari Kedua model tindak pidana tersebut diatasmempunyai hubungan erat antara satu dengan yang lainnya. Karena pidana pembunuhan itu biasanya diawali dengan penganiayaan.

Penganiayaan subsider biasanya diawali dengan tuntutan penganiayaan lalu pembunuhan punterjadi beserta adanya suatu pembuktian di pengadilan.

Sesuai dengan latar belakang yang telah disebutkan diatas, maka dapat saya rumuskan permasalahan sebagai berikut :

Bagaimana penerapan sanksi tindak pidana penganiayaan oleh jaksa penuntut umum dalam perkara Nomor 26/Pid.B/2016/PN.Tab?

Bagaimana pertimbangan hakim dalam putusan perkara tindak pidana penganiayaanNomor 26/Pid.B/2016/PN.Tab?

Penelitian ini bertujuan untuk :

Untuk mengetahui dasar pertimbangan pembuktian tindak pidana penganiayaan oleh jaksa penuntut umum.

Untuk mengetahuipertimbangan hakim dalam putusan perkara tindak pidana penganiayaan.

\section{Metode}

Dalam penelitian ini penulis menerapkan tipe penelitian hukum normatif.Penelitian hukum yang menganalisis suatu hukum tertulis pada berbagai aspek, yaitu aspek teori, materi konsistensi penjelasan umum dan pasal demi pasal yaitu disebut dengan penelitian hukum normatif. Berdasarkan dengan penelitian hukum yang digunakan ialah normatif lalu pendekatan masalah yang digunakan ialah pendekatan konseptual, pendekatan perundang-undangan dan pendekatan kasus.

Sumber hukum dalam penelitian ini, antara lain:

Mempunyai sifat mengikat sebagai 
peraturan perundang-undangan yang berlaku dan mempunyai keterkaitan dengan permasalahan yang dibahas adalah bahan hukum primer yaitu dari:

\section{a. Kitab Undang-Undang Hukum Pidana}

b. UU Nomor 48 Tahun 2009 Tentang Kekuasaan Kehakiman,Lembaran Negara Republik Indonesia Tahun 2009 Nomor 157

c. UU Nomor 8 Tahun 1981 Tentang Hukum Acara Pidana, Lembaran Negara Republik Indonesia Tahun 1982 Nomor 76

d. Berkas Perkara NO. REG PERKARA: PDM-12/TBNAN/04.2016 atas nama terdakwa I Ketut Sindu.

2. Bahan hukum sekunder ialah bahan hukum yang memiliki sifat yang di jelaskan oleh bahan hukum primer. Yakni bahan hukum sekunder berupa buku literatur, hasil karya sarjana untuk memperluas wawasan penulis mengenai bidang penulisan.

Teknik yang digunakan untuk pengumpulan bahan hukum yang dibutuhkanuntuk penelitian skripsi ini didapatmelaluicara mekakukan pembelajaran kepustakaan. Pendapatan bahan hukum lewat pembelajaran kepustakaan dikumpulkan memakai cara mencari dan mempelajari serta memahami buku-buku ilmiah,agar dapatmenampung pendapat beberapa sarjana. Selain itu, peraturan perundang-undangan yang memiliki hubungan erat kaitannya dengan pembahasan skripsi ini juga ditampung menjadi satu kesatuan. Bahan hukum yang telah berhasil ditampung dan tercatat selanjutnya dilakukan proses penyuntingan bahan hukum, pengklarifikasian bahan hukum yang relevan, penguraian secara sistematis.

Analisis bahan hukum sudah digunakan dalam penelitian ini yaitu,memakai metode deduktif, ialah metode meganalisis peraturan perundang-undangan untuk hal umum, setelah itudapat ditarik kesimpulan yang bersifat khusus. Kemudian membahas, mesusun, menguraikan dan menafsirkan, serta mengkaji permaslahan sehingga mendapat suatu kesimpulan untuk upaya pemecahan masalah.

\section{Hasil Penelitian Dan Pembahasan}

\section{Penerapan Sanksi Tindak Pidana Penganiayaan Oleh Jaksa Penuntut Umum Dalam Perkara Nomor 26/Pid.B/2016/Pn.Tab.}

Adapun penjatuhan sanksi terhadap tindak pidana penganiayaan yang dalam pasal 351 ayat
(1) KUHP telah bersesuaian dengan pasal 3 peraturan Mahkamah Agung Republik Indonesia No.2 Tahun 2012 tentang penyesuaian batasan tindak pidana ringan dan jumlah denda dalam KUHP (Peraturan Mahkmah Agung Republik Indonesia No.2 tahun 2012 tentang penyesuaian batasan pidana ringan dan jumlah denda dalam KUHP).

Tiap jumlah maksimum hukuman denda yang diancam dalam KUHP kecuali pasal 303 ayat 1 dan ayat 2,303 bis ayat 1 dan ayat 2, dilipat gandakan menjadi 1.000(seribu) kali.

Rumusan ketetapan pidana dalam tercantum dalam pasal 351 ayat (1) KUHP bersifat alternative:

"Pidana penjara paling lama dua tahun delapan bulan atau pidana denda paling banyak empat ribu lima ratus rupiah"

Perbuatan terdakwa tersebut sebagaimana diatur dan diancam pidana berdasarkan Pasal 351 ayat (1) Kitab Undang-Undang Hukum Pidana.

Barang Bukti yang dijatuhkan ke persidangan berupa

1 (satu) buah kaos warna kuning ada bekas bercak darah.

Barang bukti diatas berhasil di sita dengan sah dalam hukum karena itu bisa dimanfaatkan dalam memperkuat pembuktian, Majelis Hakim sudah menunjukan barang bukti itu kepada terdakwa dan saksi-saksi, dari yang bersangkutan telah membenarkannya.

Bahwa dalam perkara terdakwa kami ajukan kemuka persidangan dengan didakwakan telah melanggar pasal 351 ayat (1) KUHP.

Berdasarkan terungkapnya fakta-fakta didalam persidangan maka kami akan membuktikan dakwaan yang kami anggap dominan mengenai unsur-unsur tindak pidana yang didakwakan yaitu melanggar pasal 351 Ayat (1) KUHP.

Bahwa penjatuhan tindak pidana penganiayaan sesuai dengan Putusan Nomor 26/Pid.B/2016/PN.Tab. Bahwa kasus ini sesuai dengan ketentuan pasal 351 Ayat (1) KUHP.

\section{Pertimbangan Hakim Dalam Putusan Perkara Tindak Pidana Penganiayaan Nomor 26/ Pid.B/2016/Pn.Tab}

$$
\text { Yang menjadi pertimbangan Majelis }
$$


Hakim apakah berdasarkan fakta-fakta hukum dari Dakwaan dan Tuntutan Jaksa Penuntut Umum tersebut terdakwa dapat dinyatakan telah melakukan tindak pidana yang di dakwakan kepadanya.

Menimbang maka Terdakwa telah di dakwakan oleh Jaksa Penuntut Umum yaitu dakwaan tunggal yang telah diatur di pasal 351 ayat (1) KUHP, yang memenuhi unsurunsurnya yakni terdiri dari :

\section{Barang Siapa}

\section{Dengan Sengaja}

\section{Melakukan Penganiayaan}

Keadaan yang memberatkan :

Perbuatan Terdakwa telah mengakibatkan korban mengalami luka.

Keadaan yang meringankan :

Terdakwa membenarkandengan terus terang perilakunya sehingga mempermudah jalannya suatu persidangan

Terdakwa sadar bersalah, menyesal dan berjanji tidak akan mengulangi lagi perbuatannya

Terdakwa tidak pernah di hukum korban

Terdakwa sudah meminta maaf kepada

Terdakwa telah berusia lanjut (60 tahun)

Menimbang, bahwa oleh karena terdakwa haruslah diberatkan dengan membayar biaya dipengadilan karena terdakwa telah dijatuhkan pidana.

Memperhatikan, pasal 351 ayat (1) KUHP dan Undang-undang Nomor 8 Tahun 1981 tentang Hukum Acara Pidana serta peraturan perundang-undangan lain yang bersangkutan.

Dalam kasus tindak pidana penganiayaan dalam putusan pengadilan Nomor 26/ Pid.B/2016/PN.Tab.yang menjadi alat bukti yang disampaikan oleh jaksa penuntut umum adalah sesuai dengan ketentuan pasal 184 Ayat (1) KUHAP meliputi :

\section{Keterangan Saksi-Saksi}

Dalam kasus tindak penganiayaan dengan Nomor 26/Pid.B/2016/PN.Tab.terdapat 4 saksi, yakni:

Ni Wayan Serning, lahir di Jatiluwih, 31 Desember 1957 (58 tahun), perempuan, agama
Hindu, suku Bali, Kewarganegaraan Indonesia, Pekerjaan swasta, alamat Banjar Dinas Jatiluwih Kangin, Desa Jatiluwih, Kecamatan Tabanan, Kabupaten Tabanan, Pendidikan SD.

2. I Wayan Kuasa, lahir GunungSari, 31 Desember 1958 (57 tahun), Laki-Laki, Pekerjaan Pensiunan PNS, Agama Hindu, Kewarganegaraan Indonesia, alamat Banjar Dinas Jatiluwih Kangin, Desa Jatiluwih, Kecamatan Penebel, Kabupaten, pendidikaan terakhir S1

3. Ni Wayan Westra, lahir Jatiluwih, 30 Desember 1958 (58 tahun), perempuan, Pekerjaan Petani, Agama Hindu, Kewarganegaraan Indonesia, alamat Banjar Dinas Jatiluwih Kangin, Desa Jatiluwih, Kecamatan Penebel, Kabupaten Tabanan, Pendidikan SD.

4. Ni Nengah Wandri, lahir di Jatiluwih, 4 Juni 1961 (55 tahun), perempuan , Pekerjaan OPetani, Agama Hindu, Kewarganegaraan Indonesia, alamat Banhar Dinas Jatiluwih Kawan.

\section{Bukti-Surat}

Visum Et Repertum No.010/199/Diskes tanggal 15 Januari 2016 yang dibuat dan di tandatangani oleh dr. Ni Nyoman Karmiyatni, dokter pemerintah pada Puskesmas Penebel dengan kesimpulan akhir pemeriksaan mengalami memar-memar pada kepala kiri, pada dahi kiri, pada kelopak mata serta lutut kiri; luka lecet pada bawah hidung kiri, pada tangan kiri, pada leher kanan, pada dada kiri serta luka robek pada bibe bawah sebelah kiri yang diduga akibat kekerasan dengan benda tumpul.

\section{Bukti-Petunjuk}

Berdasarkan pasal 188 Ayat (1) KUHAP petunjuk adalah perbuatan, kejadian atau keadaan yang karena persesuaian, baik antara yang satu dengan yang lain, mampu dengan tindak pidana itu sendiri, menandakan bahwa telah terjadi suatu tindak pidana, petunjuk sebagaimana dimaksud dalam Ayat (1) tersebut diproleh antara lain dari keterangan saksi-saksi Ni Wayan Serning, I Wayan Kuasa, Ni Wayan Westra, NI Nengah Windari, keterangan terdakwa dan barang bukti yang diajukan dipersidangan, yang berdasarkan fakta-fakta yang terungkap dipersidangan.

\section{Keterangan Terdakwa}

Membenarkan identitasnya sesuai dengan yang tertera dalam Surat Dakwaan dan 
dalam perkara ini terdakwa tidak menggunakan haknya untuk didampingi Penasehat Hukum, serta menyatakan mengerti dengan Dakwaan Penuntut Umum, terhadap Dakwaan tersebut Terdakwa tidak mengajukan Eksepsi.

\section{Simpulan}

Didasarkan dari hasil penelitian dan pembahasan tersebut di atas, jadi penulis bisa menarik kesimpulan yakni :

Menerapkan sanksi tindak pidana penganiayaan oleh jaksa penuntut umum pada perkara Nomor 26/Pid.B/2016/PN.Tab. dijatuhkan pasal 351 ayat (1) KUHP dan yang disesuaikan didasarkan pasal 3 peraturan Mahkamah Agung Republik Indonesia No.2 Tahun 2012 tentang penyesuaian batasan tindak pidana ringan dan jumlah denda dalam KUHP. Terdakwa dalam putusan ini dijatuhkan pidana 4 (empat) bulan penjara. Sesuai dengan pandangan penulis bahwa pelaku sepantasnya dikenakan ancaman sesuai dengan ketentuan pasal 351 Ayat (1) KUHP Adapun unsur-unsur penganiayaan yang terdapat dalam Pasal 351 KUHP yaitu adanya kesengajaan, adanya perbuatan, adanya akibat perbuatan (yang dituju), rasa sakit pada tubuh, dan atau luka pada tubuh, akibat yang menjadi tujuan satusatunya.

Pertimbangan hakim pada putusan perkara tindak pidana penganiyaan Nomor 26/ Pid.B/2016/PN.Tab, Dimana pertimbangan Hakim yang memberatkan dimana terdakwa mengakibatkan saksi korban mengalami luka.

Dan adapun pertimbangan Hakim yang meringankan meliputi :

Terdakwa membenarkan dengan terus terang perilakunya sehingga mempermudah jalannya suatu persidangan.

Terdakwa sadar bersalah menyesal dan berjanji tidak akan mengulangi perbuatannya.

Terdakwa belum pernah di hukum. korban.

Terdakwa sudah meminta maaf kepada

Terdakwa telah berusia lanjut yaitu sudah berusia (60 Tahun).

Hal-hal tersebut diatas yang menjadikan pertimbangan Hakim dalam menjatuhkan pidana kepada terdakwa, dengan mempertimbangkan ketentuan pasal 351 Ayat (1) KUHP dan Undang-undang Nomor 8 Tahun
1981 tentang Hukum Acara Pidana.

\section{Daftar Pustaka}

Ali, A. (2002). Menguak Tabir Hukum Suatu Kajian Filosofis dan Sosiologis. Jakarta: PT Toko Gunung Agung.

L.Diab, A. (2014). Peranan Hukum Sebagai Social Control, Social Engineering Dan Social Welfare. Jurnal Al-'Adl, 7(2). Retrieved from https:// jurnal.unimed.ac.id/2012/index.php/ jupiis/article/download/9651/ $\underline{9066}$

Puspitasari, I. A. I., \& Rofikah. (2019). Pertanggungjawaban Pelaku Tindak Pidana Pembunuhan Dengan Mutilasi Yang Mengidap Gangguan Jiwa Skizofrenia. Jurnal Hukum Pidana Dan Penanggulangan Kejahatan, 8(2). Retrieved from https://jurnal.uns.ac.id/recidive/ article/view/40621/26778

Peraturan Mahkmah Agung Republik Indonesia No.2 tahun 2012 tentang penyesuaian batasan pidana ringan dan jumlah denda dalam KUHP. 